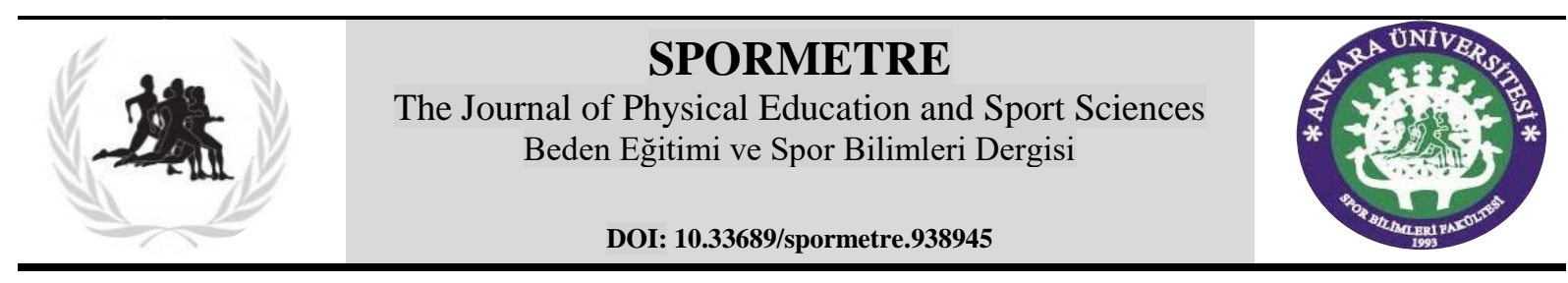

Geliş Tarihi (Received):18.05.2021

Kabul Tarihi (Accepted):18.10.2021

Online Yayın Tarihi (Published): 30.12.2021

\title{
THE MOVEMENT IMAGERY QUESTIONNAIRE-3: RELIABILITY AND VALIDITY STUDY ON TURKISH SAMPLE
}

\author{
Yunus Ugur $^{1^{*}(\mathbb{D})}$, Hamit Coskun ${ }^{1}$, , Ahmet Yasin Senyurt $^{2}$ (i) \\ ${ }^{1}$ Bolu Abant Izzet Baysal University, Faculty of Science and Literature, Department of Psychology, BOLU \\ ${ }^{2}$ Balikesir University, Faculty of Science and Literature, Department of Psychology, BALIKESIR
}

\begin{abstract}
This study aimed to investigate the psychometric properties of the Movement Imagery Questionnaire3 (MIQ-3) (Williams et al., 2012), among a Turkish sample. The study was conducted with 127 (97 women, 30 men) university students. Participants are in the 19-29 age range (Mage $=20.97, \mathrm{SD}=1.67$ ). 81 of the participants $(59.6 \%)$ reported that they were licenced athletes before. The questionnaire that consists of three subscales (internal-visual imagery, external-visual imagery, kinesthetic imagery), was developed to assess the imagery ability of individuals towards certain basic movements. The participants were asked to rate the level of ease/difficulty of the imagery task of these movements on a 7-point scale $(1=$ very hard to see/feel; $7=$ very easy to see/feel). The results showed that the goodness of fit indices was satisfactory, $(\chi 2(48)=72.10 p=.01$, $\mathrm{CMIN} / \mathrm{DF}=1.50, \mathrm{CFI}=.94, \mathrm{TLI}=.92, \mathrm{SRMR}=.05, \mathrm{RMSEA}=.06(90 \% \mathrm{CI}=0.06-0.07) .0 .75 \mathrm{CR}$ and 0.43 AVE values for the internal-visual imagery subscale, $0.76 \mathrm{CR}$ and $0.46 \mathrm{AVE}$ values for the external-visual imagery subscale, and $0.84 \mathrm{CR}$ and $0.57 \mathrm{AVE}$ values for the kinesthetic imagery subscale was obtained. In conclusion, we suggest that the Turkish version of the "MIQ-3" has good psychometric properties in measuring individuals' imagery ability.
\end{abstract}

Key Words: Imagery, imagery ability, questionnaire, validity and reliability study

\section{HAREKET İMGELEME ÖLÇEĞİ: TÜRKIYYE ÖRNEKLEMİ ÜZERİNDE GEÇERLIK VE GÜVENIRLİK ÇALIŞMASI}

Öz: Bu çalışmanın amacı, Hareket İmgeleme Ölçeği-3'ün (Williams ve ark., 2012), Türkiye örneklemi üzerindeki güvenirlik ve geçerliğini test etmektir. Çalışma 127 (97 kadın, 30 erkek) üniversite öğrencisi ile gerçekleştirilmiştir. Katılımcılar 19-29 yaş aralığındadır (Xyaş = 20.97, $S s=1.67)$. Katılımcıların 81'i $(\% 59,6)$ daha önce lisanslı olarak sporla ilgilendiğini bildirmiştir. 12 madde ve üç alt boyuttan (içsel-görsel imgeleme, dışsal-görsel imgeleme, kinestetik imgeleme) oluşmakta olan ölçek bireylerin belirli temel hareketlere yönelik imgeleme yeteneklerini değerlendirmek için geliştirilmiştir. Katılımcılardan bu hareketlere dair imgeleme görevinin kolaylık/zorluk düzeyini 7'li (1= Görmek/Hissetmek çok zor-7=Görmek/Hissetmek çok kolay) bir ölçekte derecelendirmeleri istenmiştir. Sonuçlar uyum iyiliği indekslerinin tatmin edici olduğunu göstermiştir, $((\chi 2(48)=72.10 \mathrm{p}=.01, \mathrm{CMIN} / \mathrm{DF}=1.50, \mathrm{CFI}=.94, \mathrm{TLI}=.92, \mathrm{SRMR}=.05, \mathrm{RMSEA}=.06(90 \% \mathrm{CI}=0.06-$ 0.07)). İçsel-görsel imgeleme alt boyutu için $0.75 \mathrm{CR}$ ve $0.43 \mathrm{AVE}$ değerleri, dışsal-görsel imgeleme alt boyutu için $0.76 \mathrm{CR}$ ve $0.46 \mathrm{AVE}$ değerleri ve kinestetik imgeleme alt boyutu için $0.84 \mathrm{CR}$ ve $0.57 \mathrm{AVE}$ değerleri elde edilmiştir. Sonuç olarak, Hareket İmgeleme Ölçeğinin Türkçe versiyonunun bireylerin imgeleme yeteneğini ölçmede psikometrik açıdan iyi bir ölçek olduğu söylenebilir.

Anahtar Kelimeler: İmgeleme, imgeleme yeteneği, anket, geçerlilik ve güvenilirlik çalışması 


\section{INTRODUCTION}

Imagery is a concept derived from the term "image". Imagery can be defined as a semi-sensory and semi-perceptual cognitive rehearsal on a task or situation without a stimulus (Driskell et al., 1994; Martin et al., 1999). In the psychology literature, imagery is defined as "... a purely mental idea that is taken as being observed by the "eye of mind". Such mental images are created or produced not by an external stimulus but by a mental act of reproduction." (Roeckelein, 2004). Imagery, mental repetition, visualization, and mental training are concepts that can be used interchangeably by sports researchers and sports experts, but the imagery is the best known and most widely used in the literature.

The contribution of imagery to athletes has been studied in the field of sports psychology for many years. Imagery, considered as one of the tools to increase performance in sports, has been extensively discussed in various aspects of the literature. Numerous empirical and review studies focused on imagery, especially in America and Europe (Driskell et al., 1994; Murphy et al., 1990; Munroe-Chandler and Hall 2004; Suinn, 1985). Driskell et al. (1994) concluded in their meta-analytic study that imagery increases sports performance. Over two decades later another meta-analytic research on the effect of imagery on performance, including 37 studies was between 1995 and 2018, confirmed that imagery effects performance positively (Toth et al., 2020). Upon examining these studies in general, they also suggested that some variables such as task type, the time between imagery and performance, and the duration of the imagery session play a moderator role in the imagery-performance relationship (Driskell et al., 1994). In a study conducted with a women's soccer team in Canada, motivational-general-mastery imagery was found to have significant effects on collective efficacy (Munroe-Chandler and Hall, 2004). Researchers tend to measure imagery ability through various scales (e.g., Hall and Pongrac, 1983), determine how often athletes use imagery (e.g., Hall et al., 1998), the effects on performance (e.g., Jones and Stuth, 1997), the effects on learning skills (e.g., MunroeChandler et al., 2012), enhancing self-efficacy (Jones et al., 2002), and support the recovery process after injury (e.g., Ievleva and Orlick, 1991). However, studies on the uses and effect of imagery in the field of sports are quite limited in our country.

The effect of imagery on sportive performance has been demonstrated many times in the literature (e.g., Lu et al., 2020; Jones and Stuth, 1997; Munroe-Chandler and Hall 2004, Rostami and Rezaee 2014; Suinn 1985; Uğur 2016; Weinberg 1982). Paivio (1985) revealed that imagery has motivational and cognitive effects on people, and these effects are combined with general and specific goals. In some studies, conducted within the framework of Paivio's model, motivational-general imagery in football (Munroe-Chandler and Hall 2004), motivational-specific imagery in basketball (Rostami and Rezaee 2014), cognitive-general imagery in golf (Uğur, 2016) were found to lead to more performance increase. Researchers have suggested that the effectiveness of imagery on sportive performance depends upon the ability of the individual to imagine (Goss et al., 1986; Martin et al., 1999; Weinberg and Gould, 2018). In line with this suggestion, one research conducted with trampoliners demonstrated that those with high imagery ability showed more improvement in motor skill learning and performance than those with the low ability (Isaac, 1992). Similarly, Start and Richardson (1964) found that those better at vitality and control had better performance. Goss et al. (1986) concluded that high imagery ability facilitated the learning of movement. However, few studies in the literature reached conflicting findings. For instance, Gregg, Hall, and Nederhof (2005) concluded that imagery ability does not predict performance. In this regard, it is of great importance in measuring the imagery ability of the athlete and even developing this ability to maximize the contributions from imagery. 
Researchers in America and Europe have tried to measure different aspects of the imagery concept through various scales. If imagery is considered as a skill, it is necessary to accept the existence of interpersonal differences in terms of imagery ability. Since the imagery ability is not measured directly in concrete and precise ways, it has been measured by methods such as questionnaires, forms, and inventories. The imagery was first measured in the literature by Betts (1909). Especially since the 1980s, studies have been conducted to assess the purposes of athletes' imagery uses for and which type of imagery they use more frequently. One of these scales is the Movement Imagery Questionnaire (MIQ) which consists of eight items and is for imagining some movements that require a certain level of ability and coordination was developed by Hall and Pongrac (1983) and later revised by Hall and Martin (1997). The most recent revision of the questionnaire is MIQ-3 modified by Williams et al. (2012). Afterwards the MIQ-3 was adapted for use with children (MIQ-C; Martini et al., 2016). The Vividness of Movement Imagery Questionnaire (VMIQ) was developed by Issac et al. (1986) to measure both the visual and kinesthetic imagery ability of the individuals. Further, the VMIQ (Isaac et al., 1986) was revised by Roberts et al. (2008) and VMIQ-2 emerged. In recent years, this questionnaire was customized for wheelchair sports by Faull and Jones (2018). The Sports Imagery Questionnaire, developed by Hall et al. (1998), is a scale used to reveal which type of imagery athletes use more frequently. Short et al. (2004) revised the Sports Imagery Questionnaire and included the function of the image rather than the frequency of the uses of the imagery. The Sport Imagery Ability Measure, developed by Martens (1982) and revised by Watt et al. (2004), emphasizes the extent to which athletes use their senses during imagery.

In our country, Kızıldağ and Tiryaki (2012) made the adaptation study of the Sports Imagery Questionnaire developed by Hall et al. (1998). The same scale was adapted to Turkish by Vurgun (2010). However, these scales were developed not to measure the individual's imagery ability but to determine the type of imagery that the athlete uses or prefers to use more frequently. Similar to the current study, the Turkish adaptation study of the MIQ revised by Williams et al. (2012), was conducted by Dilek et al. (2020) in the field of physical therapy and rehabilitation.

In the present study, the MIQ-3 by Williams et al. (2012), the modified version of the MIQRevised (MIQ-R) by Hall and Martin (1997), was used. This version of the questionnaire is the most current version. The questionnaire, consisting of 12 items and three subscales (internalvisual imagery, external-visual imagery, kinesthetic imagery), was developed to measure the imagery ability of individuals through certain basic movements. In this regard, the participants were asked to perform physically four basic movements (arm movement, jumping, knee lift, and waist bend) firstly. Then, it was asked to image the movements one by one) visually or kinesthetically before rating the ease/difficulty level of this mental task s on a 7-point scale.

Because of the absence of a tool developed or adapted to directly assess the imagery ability on a sample of athletes in Turkey, it was necessary to adapt the questionnaire to Turkish to eliminate the lack in this issue. In this context, we planned to adapt MIQ-3 was revised by Williams et al. (2012) to Turkish to measure the imagery ability and to conduct validity and reliability studies on the Turkish sample. Therefore, the present study will make significant contributions both to the sports psychology literature as a tool to increase the number and quality of research to be conducted in our country, and to the practices of professionals involved in sports. 


\section{METHOD}

\section{Research Model}

The recent study is a methodological study designed to test the validity and reliability of the "Movement Imagery Questionnaire-3" by Williams et al. (2012) among the Turkish sample.

\section{Participants}

A total of 136 university students, 104 female $\left(M_{\text {age }}=20.92, S D=1.51\right)$ and 32 males $\left(M_{\text {age }}=\right.$ $21.13, S D=2.14)$ participated in the study $\left(M_{\mathrm{age}}=20.97, S D=1.67 .59 .6\right) .81$ participants $(59.6$ $\%)$ stated that they were interested in sports as licensed before, and the remaining $55(40.4 \%)$ stated that they were not professionally interested in any sport. The participants did not have a physical obstacle or an injury to performing the four movements on the questionnaire and they have the ability to physically perform the movements. They had not received any imagery training in the past. All the participants signed the informed consent form and participated in the research voluntarily. The Bolu Abant Izzet Baysal University Human Research Ethics Committee (Protocol number - Date: 2021/93 - 01.03.2021) approved this study.

In the studies of the original version of the MIQ-3, different participant groups such as studentathletes (sport science students), football players, dancers and swimmers were used (see Williams, et al., 2012, p. 625). Besides, in the literature, the MIQ-3 was used in numerous researches with different groups (e.g., basketball-Mendes et al., 2015; futsal-Quinton et al., 2014; soccer and swimming-Duarte-Mendes et al., 2019; individual and team sports-Williams, et al., 2015) is also used as a tool. So, it can be said that the MIQ-3 is not specific to any group, on the contrary, it can be used for every group from individuals who are interested in sports or exercise as a hobby to elite athletes who are professionally interested in.

\section{Materials}

Demographic Information Form: The demographic information form was created by the researchers and had a total of 8 questions to gather information about participants' age, gender, license status, license period, sports branch, any health problems, or injury may prevent the study, interests in sports and participation a scientific study or training related to imagery.

Movement Imagery Questionnaire-3 (MIQ): The Revised Movement Imagery Questionnaire (MIQ-R) was initially developed by Hall and Martin (1997), and MIQ-3 is the current version of the scale as revised by Williams et al. (2012). The questionnaire consisted of 12 items and three subscales (i.e., internal-visual imagery, external-visual imagery, and kinesthetic imagery) to measure the imagery ability of individuals. In this direction, the participants imagined these movements after performing four basic movements (arm movement, jumping knee lift, waist bend). Finally, they were asked to evaluate the ease/difficulty level of the imagery task on a 7point scale $(1=$ very hard to see/feel; $7=$ very easy to see/feel $)$. A previous study reported no significant difference between genders (Williams et al., 2012). In the reliability study of the scale, instead of the internal consistency coefficient, composite reliability (CR) and average variance extracted (AVE) values were taken as a basis. The scale had CR coefficients of .83 for external-visual imagery, .79 for internal-visual imagery, and .85 for kinesthetic imagery, .55 for external-visual imagery, .52 for internal-visual imagery, and .59 for kinesthetic imagery.

\section{Translation Procedure}

First, permission was gotten from the researchers of the MIQ-3 via e-mail and a copy was obtained. Then, as the first step, the process of translating the questionnaire from English to Turkish was started. Translation of the MIQ (Williams et al., 2012) into Turkish was done 
within the framework of the committee approach. The committee approach is a translation process method that has been widely adopted in the literature in recent years (Taner and Seferoğlu, 2016). With the committee approach developed by Harkness (2003), the translation process is carried out in some stages. In the present study, first, the scale was translated into Turkish by two independent researchers who are knowledgeable in the area and who are good command of English. Then, in the second stage, the translated questionnaire, with the help of another researcher, was re-edited by comparing it with the original version, and the suggestions were discussed among the researchers. Finally, with the participation of another independent judge, alternatives on translation were evaluated and the final version of the questionnaire was agreed upon. At this stage, the questionnaire was ready for a pre-test. A pilot study with a sample group of participants was carried out individually within groups of four in the laboratory as planned in the main study. In addition to the responses of the participants to the items, the information obtained through their self-reports about the problems they experienced during the application and the observations of the researcher about the problems experienced in the application were also recorded. After the pilot study, because of the work carried out with the translation team, the necessary corrections were made, and the questionnaire was ready for validity and reliability studies.

\section{Data Collection Procedure}

For the research, the students at the university where the authors are in were invited to participate in the research for receiving course credits in return. General information about the nature of the research was provided by the researcher to the participants who answered the call positively participants were taken to the laboratory in groups of four at most. The purpose of carrying out the application phase of the questionnaire in the laboratory environment is to ensure that the application is carried out in a controlled environment in the presence of the researcher to minimize the possible mistakes that the participants may make during movement and mental tasks.

The participants first fill out the demographic information form. After that, they were informed about the points that they should pay attention to during the research, and the questionnaire was applied. Instructions were read by the researcher in a way that all participants could hear, and the participants could follow the instructions from the form. The application was generally carried out in three stages. In the first stage, each of the four different movements in line with the instructions was performed out by the participants on the relevant item. Just before the performing the movement, they stood up and took their places in the laboratory with the help of a cover so that they could not see each other. In the second stage, the mental task related to the movement, as carried out in line with the instructions given by the researcher. Since there was no information about the duration of the mental task on the questionnaire, the participants completed the mental task in a time close to the time they spent for performing the movement. Finally, the ease level of the mental task was rated by the participants on a 7-point scale. The whole process was applied in the same way for each of the 12 items, and the application was completed in an average of 15 minutes for each participant. The researcher thanked all the participants and also who requested information were informed about the application process of the research in a way that would not affect the research process. The entire data collection process was completed in approximately a month.

\section{Data Analysis}

Before starting the analysis, nine out of 136 participants were not included in the analysis because they were determined as outlier because of univariate (z-score) and multivariate (Mahalanobis and Cooks distance) analysis. Analysis was conducted with the remaining 127 
participants. To test the normality of data, skewness and kurtosis values were check upon. The data showed that values of skewness and kurtosis were between acceptable range based on the assumptions of Bryne (2010) and Tabachnick and Fidell, (2008). So, the data was considered to be normal.

The Turkish version of MIQ-3's factor structure was analyzed through confirmatory factor analysis and validity studies by IBM SPSS-26 and AMOS-23. In the original version of the questionnaire, the authors used the CR and AVE values due to the limitations of the Cronbach Alpha coefficient (Williams et al., 2012). In the present study, both Cronbach's Alpha, CR and AVE values were examined to evaluate the validity and reliability of the questionnaire. CR was considered to evaluate reliability and AVE was considered to evaluate divergent validity. In the confirmatory factor analysis to test model fit chi-square $\left(\chi^{2}\right)$, relative chi-square index (CMIN/DF), root mean square error (RMSEA), standardized root mean square residual (SRMR), Comparative fit index (CFI), and Tucker Lewis index (TLI) values were calculated.

\section{RESULTS}

\section{Analyzes on Demographic Data}

The total scores of the participants from the Movement Imagery Questionnaire were analyzed to determine whether there would be a difference between genders. The independent t-test analysis showed no significant difference between female $(M=68.30)$ and male $(M=70.83)$ in terms of imagery ability, $t(125)=-1.42, p=.16$. Besides, based on Levene Tests for all subscales and for the MIQ-3, the variances were equal for male and female ( $p$ values between .09-.93). Also, no significant relationship was found between imagery ability and age, $r=.03$, $p=.74$ as well as between interest in sports and imagery ability, $r=.08, p=.35$.

\section{Validity Results}

Although there is no general consensus in the literature about the number of participants required for factor analysis, researchers suggest a sample size which is 2 to 10 times of the number items in the scale (Büyüköztürk, 2002; Child, 2006; Kline, 2014). The questionnaire in the present study consisted of 12 items. In line with these suggestions in the literature, the factor analysis was conducted with 127 participants in the present study.

$\underline{\text { Table 1. Factor loadings (pattern matrix) }}$

\begin{tabular}{|c|c|c|c|c|c|c|c|c|c|c|c|c|}
\hline 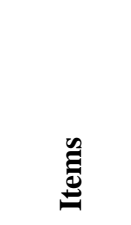 & 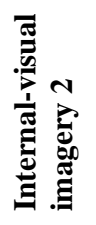 & 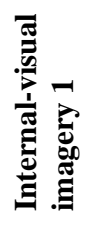 & 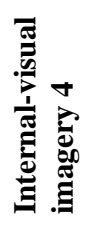 & 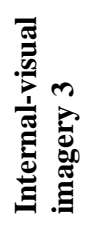 & 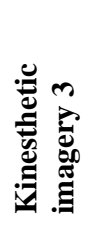 & 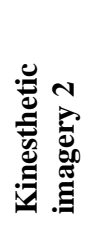 & 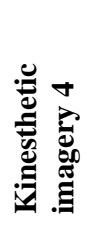 & 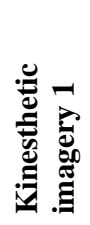 & 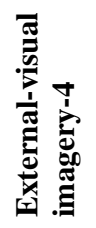 & 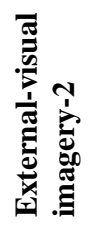 & 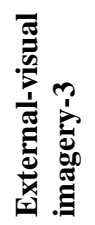 & 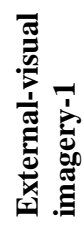 \\
\hline Factor-1 & .892 & .636 & .539 & .458 & & & & & & & & \\
\hline Factor-2 & & & & & .818 & .818 & .800 & .563 & & & & \\
\hline Factor-3 & & & & & & & & & .866 & .700 & .600 & .419 \\
\hline
\end{tabular}

Confirmatory factor analysis was performed through SPSS and AMOS. The sample size according to $\mathrm{KMO}$ and Bartlett test was suitable for factor analysis, $\mathrm{KMO}=.79, p=.0001$. The confirmatory factor analysis indicates that the questionnaire consists of three subscales as it was in its original form. The Direct Oblimin rotation method was used because the subscales were interrelated to each other (Williams et al., 2012). As shown in the pattern matrix, items measure the kinesthetic imagery subscale (Item 1-4-7-10) were on the same structure loading on the first 
factor, items measure the internal-visual imagery subscale (Item 2-5-8-11) were on the second factor, and the items measure the external-visual imagery subscale (Item 3-6-9-12) were on the third factor. Factor loadings were at reasonable levels (Table 1). The total variance explained was $57.82 \%$.

Table 2. Goodness-of-fit indices

\begin{tabular}{lcccc}
\hline Index & Value & Good fit & Acceptable Value & Criteria \\
\hline $\mathbf{x}^{\mathbf{2}}$ & 72.10 & - & & - \\
$\mathbf{x}^{2} /$ Sd & 1.50 & $<2$ & $<3$ & Normal \\
RMSEA &, 06 & $<0,05$ & $<0,08$ & Acceptable \\
CFI & .94 & $>0,95$ & $>0,90$ & Acceptable \\
SRMR &, 05 & $<0,05$ & $<0,08$ & Acceptable \\
TLI & 92 & $>0,95$ & $>0,90$ & Acceptable \\
\hline
\end{tabular}

Based on the confirmatory factor analysis, when looking at fit indices, model-data fit was sufficient, $\chi^{2}(48)=72.10 p=.01, \mathrm{CMIN} / \mathrm{DF}=1.50, \mathrm{CFI}=.94, \mathrm{TLI}=.92, \mathrm{SRMR}=.05$, RMSEA $=.06(90 \% \mathrm{CI}=0.06-0.07)$ (Hooper et al., 2008; Hu and Bentler, 1999; Zainudin, 2012). Table 2 shows the fit indices. The model was shown in Figure 1. Also, significant relationships were seen among subscales as expected. The correlation between internal-visual imagery and external-visual imagery was $r=.74$, the correlation between kinesthetic imagery and internalvisual imagery was $r=.51$, and the correlation between external-visual imagery and kinesthetic imagery was $r=.34$.

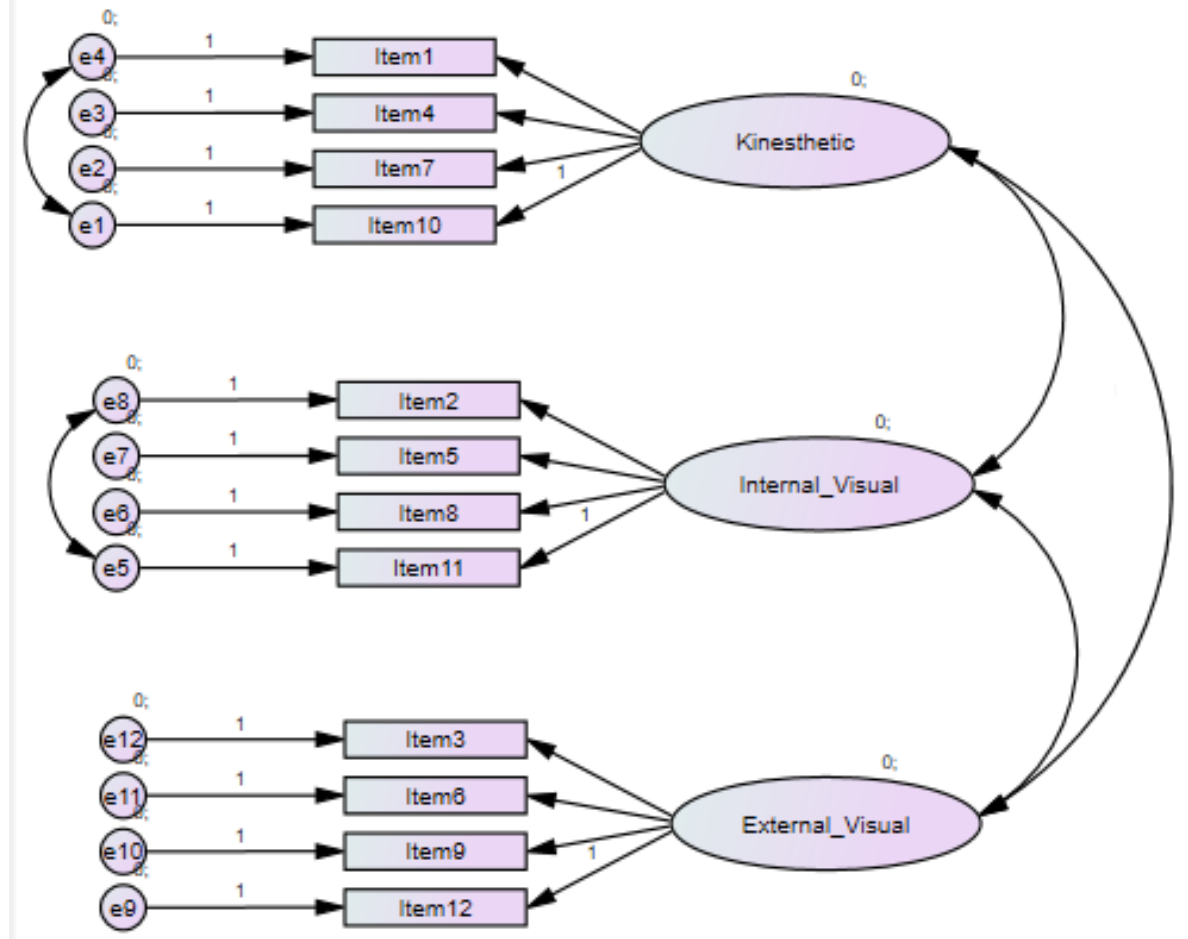

Figure 1. The path diagram of the movement imagery questionnaire

\section{Reliability Findings}

The Cronbach Alpha values were $\alpha=.78$ for the kinesthetic imagery subscale, $\alpha=.71$ for the internal-visual imagery subscale and, $\alpha=.69$ for the external-visual imagery, and $\alpha=.81$ for 
the whole questionnaire. In the present study, $0.75 \mathrm{CR}$ and $0.43 \mathrm{AVE}$ were obtained for the internal-visual imagery subscale, $0.85 \mathrm{CR}$ and $0.57 \mathrm{AVE}$ values for the external-visual imagery subscale, and 0.76 CR and 0.46 AVE for the kinesthetic imaging subscale. Table 3 illustrates validity and reliability test results.

Table 3. Validity and reliability test results: MIQ-3 vs. MIQ-3 Turkish version

\begin{tabular}{lccccc}
\hline Subscale & $\begin{array}{c}\text { Cronbach } \\
\text { Alpha }\end{array}$ & CR & $\begin{array}{c}\text { CR (Williams } \\
\text { et al., 2012) }\end{array}$ & AVE & $\begin{array}{c}\text { AVE } \\
\text { (Williams et } \\
\text { al., 2012) }\end{array}$ \\
\hline Internal-visual & .71 & .75 & .79 & .43 & .52 \\
External-visual & .69 & .76 & .83 & .46 & .55 \\
Kinesthetic & .78 & .84 & .85 & .57 & .59 \\
\hline
\end{tabular}

In addition, data was analyzed for split-half-reliability. The correlation coefficient between the two forms was .73, the Spearman-Brown correlation coefficient was .84 and the Gutmann splithalf coefficient was .84 .

\section{DISCUSSION}

Based on the current findings, Movement Imagery Questionnaire is valid and reliable in Turkish sample, all in all. Williams et al. (2012) found that the MIQ-3 did not differ between genders. The same result was obtained in the present study, and no difference was found between males and females. An interesting finding was that there was no correlation between the participants' interest in sports and their imagery ability. Again, no relationship was found between the age of the participants and their score on the questionnaire. The results show that the data meet the assumptions required for validity and reliability analysis. Besides, as the participants' interest in sports increased, there was no change in their imagery ability, which indicates that the data obtained from the current sample are suitable for the necessary analysis. In other words, it can be said that there is no relationship between the imagery ability of the participants and their interest in sports.

Cronbach Alpha values were satisfactory for both the whole questionnaire and the subscales. Regarding the CR and AVE values, the values of both values were sufficient for all subscales according to the cut-off values. In the original version of the questionnaire, the authors determined a cut-off value of .70 for the CR value and .50 for the AVE. However, according to Fornell and Larcker (1981), when these two values are taken together, even if the AVE values fall below .50 and above roughly .40 the convergent validity of the structure is considered sufficient if the CR values are above .60. In the literature these values, even lower ones, are accepted in different studies (e.g., Konaszewski et al., 2019; Lam, 2012). In the present study the CR value of all subscales meets the reasonable level, that is .60 , according to Fornell and Larcker (1981). Even though AVE values for two subscales (.43 and .46) less than perfect level $(<.50$.), the CR values of all subscales $(.75, .76$ and .84$)$ is well above the acceptable level and taken together with the values of Cronbach alpha $\mathrm{CR}$ values of the constructs indicate that the items have a good internal reliability. Also, both values were compatible with the values obtained in the original study of the questionnaire (Table 3). In addition to this, split half reliability results showed good acceptable and sufficient coefficients. When all these findings are taken together, it can be said that the scores of the participants measure the imagery ability of them in a reliable way. 
The construct validity of the questionnaire was tested with confirmatory factor analysis. The construct validity of a structure should be performed depending on the values of the confirmatory factor analysis (Kline, 2014). The analysis showed that the variance explained was sufficient. Also, all the questionnaire items were collected under subscales assumed to be related as in the original version and had a sufficient level of factor loadings. Considering the fit of the data with the model, the fit indexes showed that the model-data fit was generally sufficient. Moreover, as in the original study of the questionnaire, significant results were obtained in correlations between subscales. In considering these findings together, the structural validity of the questionnaire is sufficient.

When all results are considered in general, The MIQ-3 had good psychometrical properties for Turkish population. This is the first and only questionnaire that helps the measure imagery ability of individuals especially in the field of sports in Turkey. This questionnaire can help individuals, especially athletes, to gain insight on their movement imagery ability. With the help of this questionnaire, imagery-based training studies or practices on increasing imagery ability can be carried out in sports, education, therapy, organizational fields, and scientific research in our country.

\section{REFERENCES}

Betts, G. H. (1909). The distribution and functions of mental imagery (No. 26). Ams Press.

Bryne, B. M. (2010). Structural Equation Modeling with Amos: Basic Concepts, Application and Programming. ( $2^{\text {nd }}$ ed.). Routledge.

Büyüköztürk, Ş. (2002). Sosyal bilimler için veri analizi el kitabı: istatistik, araştırma deseni, SPSS uygulamaları ve yorum. [Data analysis handbook for social sciences: statistics, research design, SPSS applications and interpretation.]. Ankara, Pegem Academy Publishing

Child, D. (2006). The essentials of factor analysis. ( $3^{\text {rd }}$ ed.). Continuum.

Dilek, B., Ayhan, Ç., Yakut, Y. (2020). Reliability and validity of the Turkish version of the movement imagery questionnaire 3: Its cultural adaptation and psychometric properties. Neurological Sciences and Neurophysiology, 37(4), 221-227. https://doi.org/10.4103/NSN.NSN_30_20

Driskell, J. E., Copper, C., Moran, A. (1994). Does mental practice enhance performance? Journal of Applied Psychology, 79(4), 481. https://doi.org/10.1037/0021-9010.79.4.481

Duarte-Mendes, P., Marinho, D. A., Serrano, J., Paulo, R., Faustino, A., Ramalho, A., Petrica, J. (2019). Differences of Imagery ability between youth soccer and swimming practitioners. Journal of Human Sport \& Exercise, 14(Proc 4), 1651-1654. https://doi.org/10.14198/jhse.2019.14.Proc4.82

Faull, A. L., Jones, E. S. (2018). Development and validation of the Wheelchair Imagery Ability Questionnaire (WIAQ) for use in wheelchair sports. Psychology of Sport and Exercise, 37, 196-204. https://doi.org/10.1016/j.psychsport.2017.11.015

Fornell, C., Larcker, D. F. (1981). Structural equation models with unobservable variables and measurement error: Algebra and statistics. Journal of Marketing Research, $18 \quad$ (3), 328-388. https://doi.org/10.1177/002224378101800313

Goss, S., Hall, C., Buckolz, E., Fishburne, G. (1986). Imagery ability and the acquisition and retention of movements. Memory \& cognition, 14(6), 469-477. https://doi.org/10.3758/BF03202518

Gregg, M., Hall, C., Nederhof, E. (2005). The Imagery Ability, Imagery Use, and Performance Relationship. Sport psychologist, 19(1), 93-99 https://doi.org/10.1123/TSP.19.1.93 
Hall, C. R., Mack, D. E., Paivio, A., Hausenblas, H. A. (1998). Imagery use by athletes: development of the Sport Imagery Questionnaire. International Journal of Sport Psychology, 29(1), 73-89.

Hall, C. R., Martin, K. A. (1997). Measuring movement imagery abilities: a revision of the movement imagery questionnaire. Journal of Mental Imagery, 21(1-2), 143-154.

Hall, C. R., Pongrac, J. (1983). Movement imagery questionnaire. University of Western Ontario.

Harkness, J. A. (2003). Questionnaire translation. In Harkness, J. A., van de Vijver, F. J., Mohler, P. P., \& Wiley, J. (Eds.). Cross-cultural survey methods (pp. 35-56). John Wiley \& Sons, Inc., Publication.

Hooper, D., Coughlan, J., Mullen, M. R. (2008). Structural equation modelling: Guidelines for determining model fit. Electronic Journal of Business Research Methods, 6(1), 53-60.

Hu, L., Bentler, P.M. (1999). Cutoff criteria for fit indices in covariance structure analysis: Conventional criteria versus new alternatives. Structural Equation Modeling: A Multidisciplinary Journal,6(1), 1-55. https://doi.org/10.1080/10705519909540118

Ievleva, L., Orlick, T. (1991). Mental links to enhanced healing: An exploratory study. The Sport Psychologist, 5(1), 25-40. https://doi.org/10.1123/tsp.5.1.25

Isaac, A. R. (1992). Mental practice: Does it work in the field? The Sport Psychologist.6(2), 192-198. https://doi.org/10.1123/tsp.6.2.192

Isaac, A., Marks, D. F., Russell, D. G. (1986). An instrument for assessing imagery of movement: The Vividness of Movement Imagery Questionnaire (VMIQ). Journal of Mental Imagery, 10(4), 23-30.

Jones, M. V., Mace, R. D., Bray, S. R., MacRae, A. W., Stockbridge, C. (2002). The impact of motivational imagery on the emotional state and self-efficacy levels of novice climbers. Journal of Sport Behavior, 25(1), 5773.

Jones, L., Stuth, G. (1997). The uses of mental imagery in athletics: An overview. Applied and Preventive Psychology, 6(2), 101-115. https://doi.org/10.1016/S0962-1849(05)80016-2

Kızıldağ, E, Tiryaki, M. (2012). Sporda imgeleme envanterinin Türk sporcular için uyarlanmasI. Spor Bilimleri Dergisi, 23(1), 13-23.

Kline, P. (2014). An easy guide to factor analysis. Routledge.

Konaszewski, K., Kolemba, M., Niesiobędzka, M. (2019). Resilience, sense of coherence and self-efficacy as predictors of stress coping style among university students. Current Psychology, 1-11.

Lam, L. W. (2012). Impact of competitiveness on salespeople's commitment and performance. Journal of Business Research, 65(9), 1328-1334.

Lu, F. J., Gill, D. L., Lee, Y. C., Chiu, Y. H., Liu, S., Liu, H. Y. (2020). Effects of visualized PETTLEP imagery on the basketball 3-point shot: A comparison of internal and external perspectives. Psychology of Sport and Exercise, 51, 101765.

Martens, R. (1982). Imagery in sport. In M. L. Howell \& A. W. Parker (Eds.), Proceedings of the Australian Sports Medicine Federation International Conference. Vol. 8. Sports Medicine: Medical and Scientific Aspects of Elitism in Sport, 213-230.

Martin, K. A., Moritz, S. E., Hall, C. R. (1999). Imagery use in sport: A literature review and applied model. The Sport Psychologist, 13(3), 245-268. https://doi.org/10.1123/tsp.13.3.245

Martini, R., Carter, M. J., Yoxon, E., Cumming, J., Ste-Marie, D. M. (2016). Development and validation of the Movement Imagery Questionnaire for Children (MIQ-C). Psychology of Sport and Exercise, 22, 190-201. https://doi.org/10.1016/j.psychsport.2015.08.008. 
Mendes, P., Marinho, D., Petrica, J. (2015). Comparison between genders in imagery ability in Portuguese basketball practitioners. Journal of Physical Education and Sport, 15(3), 391.

Munroe-Chandler, K. J., Hall, C. R. (2004). Enhancing the collective efficacy of a soccer team through motivational general-mastery imagery. Imagery, Cognition and Personality, 24(1), 51-67. https://doi.org/10.2190/UM7Q-1V15-CJNM-LMP4

Munroe-Chandler, K. J., Hall, C. R., Fishburne, G. J., Murphy, L., Hall, N. D. (2012). Effects of a cognitive specific imagery intervention on the soccer skill performance of young athletes: Age group comparisons. Psychology of Sport and Exercise, 13(3), 324-331. https://doi.org/10.1016/j.psychsport.2011.12.006

Murphy, S., Jowdy, D., Durtschi, S. (1990). Report on the US Olympic Committee survey on imagery use in sport. Colorado Springs, CO: US Olympic Training Center.

Paivio, A. (1985). Cognitive and motivational functions of imagery in human performance. Canadian Journal of Applied Sport Sciences, 10, 22-28.

Quinton, M. L., Cumming, J., Gray, R., Geeson, J. R., Cooper, A., Crowley, H., \& Williams, S. E. (2014). A PETTLEP imagery intervention with young athletes. Journal of Imagery Research in Sport and Physical Activity, 9(1), 47-59.

Roberts, R., Callow, N., Hardy, L., Markland, D., Bringer J. (2008). Movement imagery ability: Development and assessment of a revised version of the vividness of movement imagery questionnaire. Journal of Sport and Exercise Psychology, 30, 200-221. https://doi.org/10.1123/jsep.30.2.200

Roeckelein, J. E. (2004). Imagery in psychology: A reference guide. Greenwood Publishing Group

Rostami, R., Rezaee, M. (2014). Prediction of cognitive and motivational functions of sports imagery in veteran basketball players. Iranian Journal of War and Public Health, 6(3), 87-93.

Short, S. E., Monsma, E. A., Short, M. W. (2004). Is what you see really what you get? Athletes' perceptions of imagery's functions. The Sport Psychologist, 18(3), 341-349. https://doi.org/10.1123/tsp.18.3.341

Start, K. B., Richardson, A. (1964). Imagery and mental practice. British Journal of Educational Psychology, 34(3), 280-284. https://doi.org/10.1111/j.2044-8279.1964.tb00638.x

Suinn, R. M. (1985). Imagery rehearsal applications to performance enhancement. the Behavior Therapist, 8(8), $155-159$.

Tabachnick, B. G., Fidell, L. S. (2008). Using Multivariate Statistics (5 ${ }^{\text {th }}$ ed.). California State University

Taner, G., Seferoğlu, G. (2016). Veri toplama araçlarının çevirisinde niteliğin arttırılması: Bir aktarım örneği. [Increasing the quality of translation of data collection tools: A transfer example] In O. Demirel, \& S. Dincer (Eds.) Eğitim Bilimlerinde Yenilikler ve Nitelik Araylşı [Innovations and the Quest for Quality in Educational Sciences] (pp. 1225-1236). Pegem Academic Publishing.

Toth, A. J., McNeill, E., Hayes, K., Moran, A. P., Campbell, M. (2020). Does mental practice still enhance performance? A 24 Year follow-up and meta-analytic replication and extension. Psychology of Sport and Exercise, 48, 101672. https://doi.org/10.1016/j.psychsport.2020.101672

Uğur, Y (2016). Imgeleme türlerinin sportif performans üzerinde etkisi [Effects of imagery types on sportive performance] (Unpublished Master Thesis). Bolu Abant Izzet Baysal University, Bolu. In Turkish with English abstract.

Vurgun, N. (2010). Sporda imgeleme anketinin Türkçeye uyarlanması ve sporda imgelemenin yarlşma kaygısı ile sportif güven üzerindeki etkisi. [Adapting the sports imagery questionnaire to Turkish and the effect of imagery in sports on competition anxiety and sportive confidence] (Unpublished $\mathrm{PhD}$ Thesis), Ege University, Izmir. In Turkish with English abstract. 
Watt, A. P., Morris, T., Andersen, M. B. (2004). Issues in the Development of a Measure of Imagery Ability in Sport. Journal of Mental Imagery, 28(3-4), 149-180.

Weinberg, R. S. (1982). The relationship between mental preparation strategies and motor performance: A review and critique. Quest, 33(2), 728-734. https://doi.org/10.1080/00336297.1981.10483754

Weinberg, R. S., Gould, D. (2018). Foundations of Sport and Exercise Psychology (7 $7^{\text {th }}$ ed). Human Kinetics.

Williams, S. E., Cumming, J., Ntoumanis, N., Nordin-Bates, S. M., Ramsey, R. Hall, C. (2012). Further validation and development of the movement imagery questionnaire. Journal of Sport and Exercise Psychology, 34(5), 621646. https://doi.org/10.1123/jsep.34.5.621

Williams, S. E., Guillot, A., Di Rienzo, F., \& Cumming, J. (2015). Comparing self-report and mental chronometry measures of motor imagery ability. European Journal of Sport Science, 15(8), 703-711.

Zainudin, A. (2012). A handbook on SEM: Structural equation modelling using amos graphics (4 ${ }^{\text {th }}$ ed). University Technology MARA PRESS. 